Sarhan, S., Elnokaly, A., Pasquire, C., and Pretlove, S. (2018). "Lean Construction and Sustainability through IGLC Community: A Critical Systematic Review of 25 Years of Experience." In: Proc. $26^{\text {th }}$ Annual Conference of the International. Group for Lean Construction (IGLC), González, V.A. (ed.), Chennai, India, pp. 933-942. DOI: doi.org/10.24928/2018/0274. Available at: www.iglc.net.

\title{
LEAN CONSTRUCTION AND SUSTAINABILITY THROUGH IGLC COMMUNITY: A CRITICAL SYSTEMATIC REVIEW OF 25 YEARS OF EXPERIENCE
}

\author{
Saad Sarhan ${ }^{1}$, Amira EInokaly ${ }^{2}$, Christine Pasquire ${ }^{3}$ and Stephen Pretlove ${ }^{4}$
}

\begin{abstract}
It has been argued that Lean Construction (LC) offers the conceptual basis and the appropriate methods and tools needed for helping the construction industry meet the challenges of sustainable development. Since 1998, a growing body of knowledge has been emerging from the IGLC community, in relation to synergies between LC and Sustainability. Both seek to reduce waste and maximise value, but through different approaches and perspectives. The most common mistake, however, is a tool-focused framework for integration, which overlooks the conceptual differences between these two initiatives. The aim of this study, therefore, is to review the progress made in understanding the linkages and inconsistencies between the two initiatives, through conducting a critical systematic literature review (SLR) and synthesising the findings of 'LC and Sustainability' studies published in IGLC conferences over the past 25 years. The findings of the study provide an overview of previous studies about the topic, reveal major limitations in approaches to LC and Sustainable Construction (SC), and divulge significant opportunities for further work that remain unexplored.
\end{abstract}

\section{KEYWORDS}

Lean Construction, Sustainability, Green, Value, Waste

\section{INTRODUCTION}

The construction industry is a significant growth industry on a global level and is a fundamental part of the economy in many parts of the world. The 'Construction 2025'

1 Lecturer in Construction Management, Lincoln School of Architecture and the Built Environment, University of Lincoln, Lincoln, LN6 7TS, Tel: +44 (0)1522 83 5395, ssarhan@lincoln.ac.uk

2 Principal Lecturer in Architecture, Lincoln School of Architecture and the Built Environment, University of Lincoln, Lincoln, LN6 7TS, Tel: +44 (0)1522 83 7178, aelnokaly@lincoln.ac.uk

3 Professor of Lean Project Management, School of Architecture Design and the Built Environment, Nottingham Trent University, NG1 4BU, Tel: +44 (0)115 848 2095, christine.pasquire@ntu.ac.uk

4 Professor of Sustainable Construction, Lincoln School of Architecture and the Built Environment, University of Lincoln, Lincoln, LN6 7TS, Tel: +44 (0)1522 83 5767, spretlove@ lincoln.ac.uk 
industrial strategy report published by UK Government forecasts the global construction market to grow by up to $70 \%$ between 2013 and 2025 (HM Government, 2013). However, the construction sector is known to be one of the largest environmental polluters, physical waste producers, and energy consumers throughout its lifecycle (Huovila and Koskela, 1998; Oyedele et al, 2013; Weinheimer et al., 2017). Due to these challenges in our built environment, including issues relating to rapid growing populations and anthropogenic climate changes, there is a significant need in advancing the industry towards sustainable development. The concept of sustainable development was first coined in the Brundtland Commission, which was set up by the United Nations, as an initiative to improve the global environmental, economic and social conditions (WCED, 1987). Sustainable Construction (SC) is the response of the construction sector to the challenge of sustainable development (Huovila and Koskela, 1998). SC could be defined as "the creation and operation of a healthy built environment based on resource-efficiency and ecological principles" (Kibert (2005, p.2). According to Kibert (1994), while the traditional approach to construction project management focuses on cost, time and quality objectives, 'sustainability in architecture and construction' expands on these criteria to include minimisation of environmental degradation, minimisation of resource depletion, contextual, social and cultural consideration and creating a healthy built environment (Elnokaly and Vyas, 2014).

At the same time, the construction industry is also frequently criticised for its inherent inefficiencies, confrontational relationships, and low rates of productivity and profit margins, in comparison to other industries (for example see, Egan, 1998; Koskela, 2000; Sarhan et al., 2017). Lean construction (LC) has been shown to be effective in helping to solve many of the industry's problems and to maximise value to the customer, through helping us to understand, identify and eliminate many of the causes and sources of (process and physical) waste in the end-to-end design and construction process (Koskela, 2000; Koskela et al., 2013; Sarhan et al., 2018). There is no commonly agreed definition of LC, but it is mostly attributed to the application of the Transformation-Flow-Value generation (T-F-V) theory of production to the construction environment (see Koskela 2000). The flow dimension of the theory (F) reveals the interdependency of tasks across the whole project process (Sarhan et al., 2018), and thus introduces the reduction of waste as an objective of production management; whilst value generation (V) brings the customer into the focus (Koskela et al., 2010). The construction sector typically recognises clients and more recently stakeholders and users, but the term 'customer' is not commonly used (Sarhan et al., 2018). In this sense, a 'customer' in LC principles could include any of the aforementioned, including the concept of next customer in the production process (see Leong and Tilley, 2008), which aims to improve integration and information flow between project suppliers; thereby reducing waste and driving behaviour towards the final product and end user value.

For these reasons, it has been argued that LC has the potential to contribute towards helping the industry to meet the challenges of sustainable development. To the best of the authors' knowledge, it is Huovila and Koskela's (1998) work that first, at least within the IGLC community, put forward the proposition that sustainability in construction can effectively be promoted and supported through LC principles. According to them, the 
principles of LC converge to the sustainability objectives in two main ways. First, through the focus on the concept of waste-reduction, LC can also reduce pollution, material and energy wastes during construction and maintenance. Secondly, through the concept of 'value', LC could be useful to clients aiming for both business and environmental and social excellence simultaneously.

Since 1998, a growing body of knowledge has been emerging from the LC community, in relation to synergies between LC and SC. From a production management perspective, it has been suggested by Koskela et al. (2010) that LC is an innovation in production theory, and that SC could be regarded as an innovation in product requirements. The link between them has also been increasingly recognised and implemented in practice. Furthermore, the concepts, tools and techniques of LC and SC themselves have been under constant refinement. This study, therefore, aims to review the progress made in understanding the linkages and inconsistencies between the two approaches, through conducting a critical systematic literature review (SLR) and synthesising the findings of 'LC and Sustainability' papers published in IGLC conferences over the past 25 years. SLRs are valuable for presenting knowledge that is unlikely to be obtained from an isolated review of individual studies (Carvalho et al., 2017). Following this introduction, the study will be divided into three parts. The next section describes the methodological approach of the study, followed by an overall summary of the research findings and analysis. Finally, the conclusions are provided.

\section{RESEARCH METHODOLOGY AND OBJECTIVES}

This study adopted a SLR and a qualitative approach to research synthesis, following the protocols recommended by Siddawy (2014) and Mellow et al. (2017). SLRs entail the use of a transparent and rigorous approach for the entire research process, in order to reduce bias and enable future replication (Mallet et al., 2012). A SLR usually relies on the use of databases that contain a large set of research publications as well as effective search mechanisms. Typically, the planning process for a SLR consists of the following steps: (1) Search method; (2) Inclusion and Exclusion Criteria (3) Search Outcome. This study used the search engine provided by the IGLC website (available on http://iglc.net/Papers), to search for 'LC and Sustainability' peer-reviewed papers published in IGLC conferences over the past 25 years. The IGLC database was selected, as this conference represents the state-of-the-art of LC research and practices from all around the world (Koladiya, 2017). The keywords used for the search query and the search outcomes are summarised in Table 1 below.

Interestingly, only 43 papers, out of all conference papers published by IGLC over the past 25 years, were found to match the various search queries conducted. Out of these, two papers were excluded based on title screening followed by an abstract review, due to their irrelevance. Thus, as a result of these efforts, 41 papers out of all IGLC papers over a span of 25 years, were found to be relevant and thus thoroughly reviewed and analysed by this study.

The study used a deductive-inductive approach for data analysis, utilising QSR NVivo 11 software, and following a "lean coding" procedure (Creswell, 2007, p.152). As 
opposed to purely inductive coding approaches where researchers usually struggle to reduce the numerous lists of generated codes to the five or six main categories or themes that they must end up with for most publications; in lean coding, the researcher starts by developing a short list of five or six themes with shorthand codes, and then continues to expand and refine their coding structure as they proceed with reviewing their databases (Creswell, 2007). Accordingly, during the data coding and analysis of the 41 papers selected for the SLR, the study focused on identifying, critically evaluating, and generating the overall picture related to the following six themes: (1) Limitations in approaches to LC; (2) Limitations in approaches to SC; (3) Opportunities for future work; (4) Main synergies between LC and SC; (5) Main Trade-offs or inconsistencies ; and (6) Potential enablers for the successful integration of LC and SC. Under each of these themes, initial codes from the SLR sample were generated, followed by axial coding leading to the development of subcategories and categories (Strauss and Corbin, 1998). Due to page constraints, this paper presents the findings and a critical discussion of the first three themes.

Table 1: Search queries and outcomes

\begin{tabular}{c|c}
\hline Keywords & No. of papers matching search queries \\
\hline Sustainability & 43 \\
\hline Sustainable & 43 \\
\hline Sustainable + Development & 6 \\
\hline Green & 31 \\
\hline Environmental & 42 \\
\hline Energy & 23 \\
\hline
\end{tabular}

\section{RESULTS AND DISCUSSION}

\section{SAMPLE ANALYSIS}

The analysis of the SLR sample enabled the study to gain an overview about the: (1) Frequency of studies over time; (2) Countries that are leading and focussing on the research topic; and (3) Research methods and approaches used.

\section{Frequency of studies over time}

As shown in Figure 1 below, studies on the integration of LC and sustainability started in 1998 with the work of Huovila and Koskela (1998). Surprisingly, no further work on the topic was explored until 2004 except for one study conducted in Brazil by Degani and Cardoso (2002) promoting the concept of 'Clean Construction'. Then, IGLC publications on the topic remained stagnant until 2005, where only one study was conducted in the USA by Luo et al., (2005) to explore how benefits of LC approaches to prefabrication can impact green project goals. Studies on the topic started blooming from 2011, and peaked in 2012 where seven studies were published in that year. Interest in the topic continued until 2016, but momentum dropped in 2017 with only 2 papers concentrating on the topic, out of 111 published papers (IGLC-25 in Greece). These findings reveal the 
slow uptake and limited amount of current research on the topic of 'LC and sustainability' within the IGLC community, despite the various theoretical and empirical supports for the synergies and benefits of their integration (see for example, Lapinski et al., 2006; Koskela et al., 2010; Nahmens and Ikuma, 2012; Ogunbiyi et al., 2014; Carvalho et al., 2017).

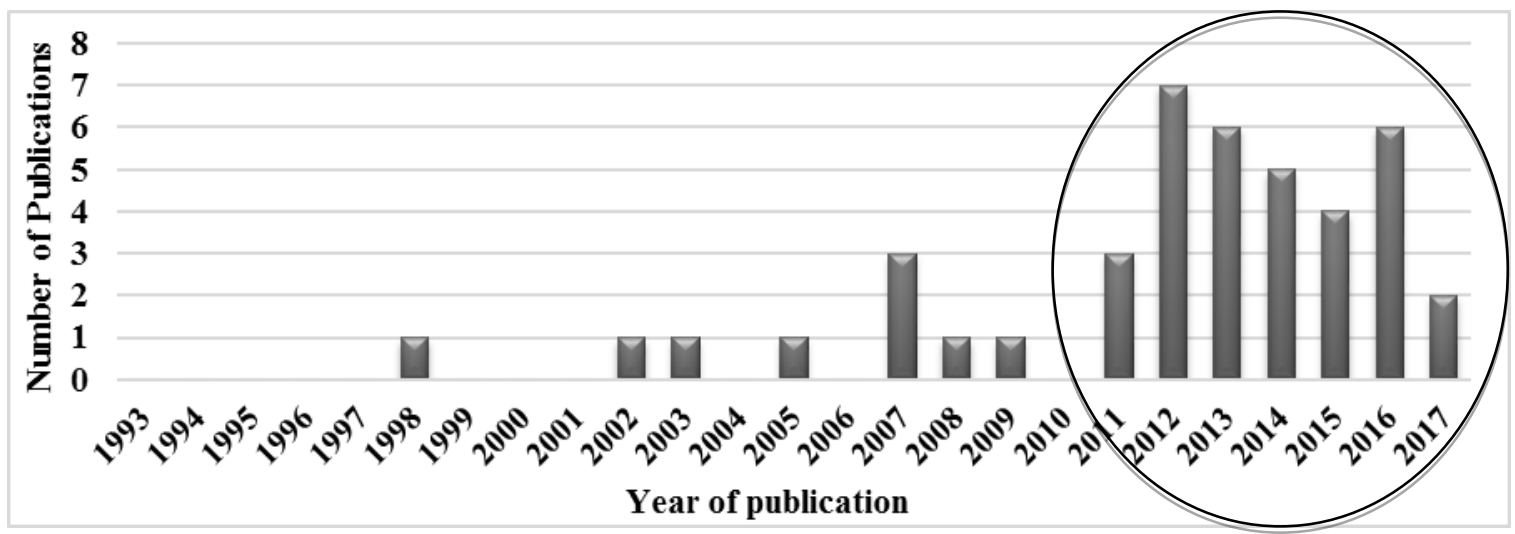

Figure 1: Number of LC-Sustainability studies per year between 1993 and 2017

\section{Geographical distribution of studies over the 25 years span}

The geographical distribution of studies scopes across 14 different countries (Figure 2), with USA and Brazil leading the way with 22 publications out of 41 (representing around $54 \%$ of the total SLR sample).

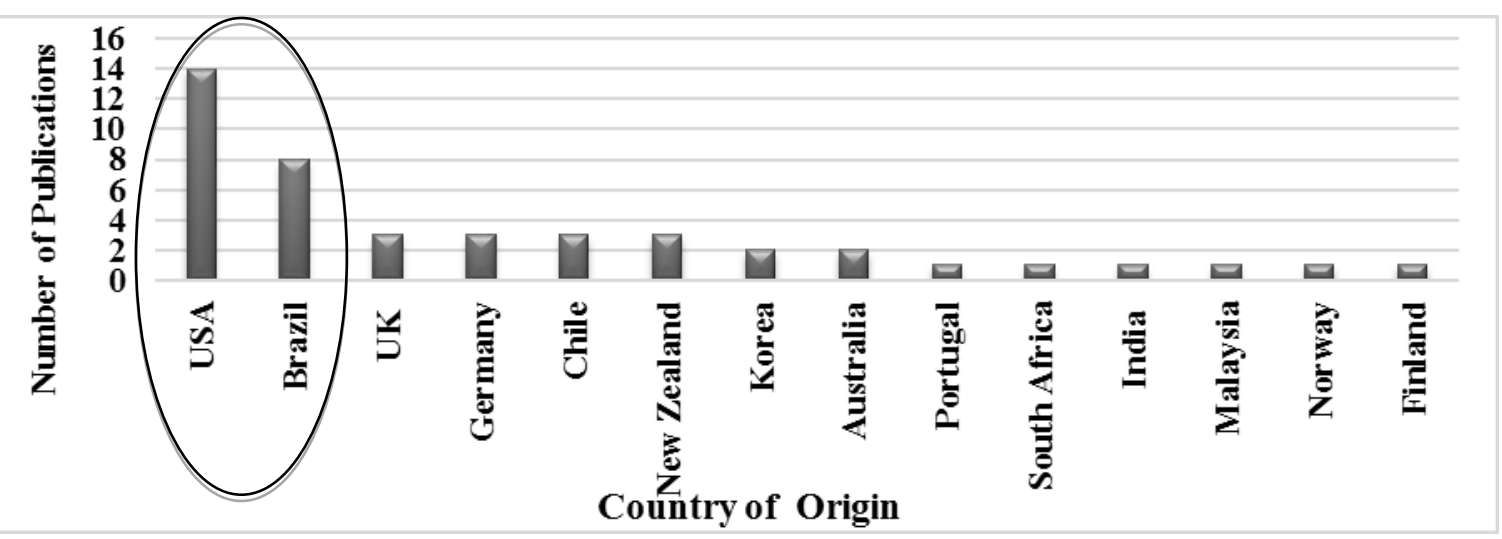

Figure 2: Geographical distribution of LC-Sustainability studies between 1993 and 2017

\section{Research methodologies and approaches used}

The SLR identified a number of varied methods used within the IGLC studies investigated (Figure 3). The results revealed that 'case-study' is the methodology mostly used $(41 \%)$ reflecting the practice-oriented nature dominating IGLC research. These findings suggest that IGLC research has possibly responded to widespread criticisms related to the extensive use of quantitative methods, associated with positivism, in mainstream construction management research (Seymour et al., 1997; Koskela, 2017). At 
the same time, the SLR also identified four research purposes and approaches utilised in the studies (Figure 4), following the classifications defined by Wu and Wang (2016).

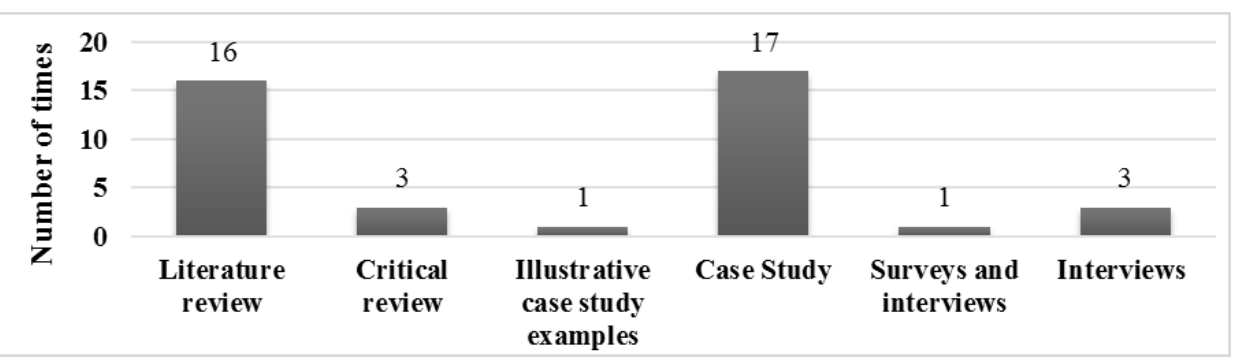

Figure 3: Research methodologies used for topics investigating LC and sustainability

The results revealed that more than two thirds of the studies were exploratory in nature, either conceptually or practically investigating the links between LC and sustainability. Furthermore, only $10 \%$ of all studies were carried out to implement and empirically quantify the results of the implementation. The first empirical implementation study was carried out in 2008, and no similar studies were conducted again until 2014. These findings clearly indicate that the integration of LC and sustainability is a topic that is still poorly researched and applied within the IGLC community. This is a growing field and much more work discussing the application of such an approach is hence needed

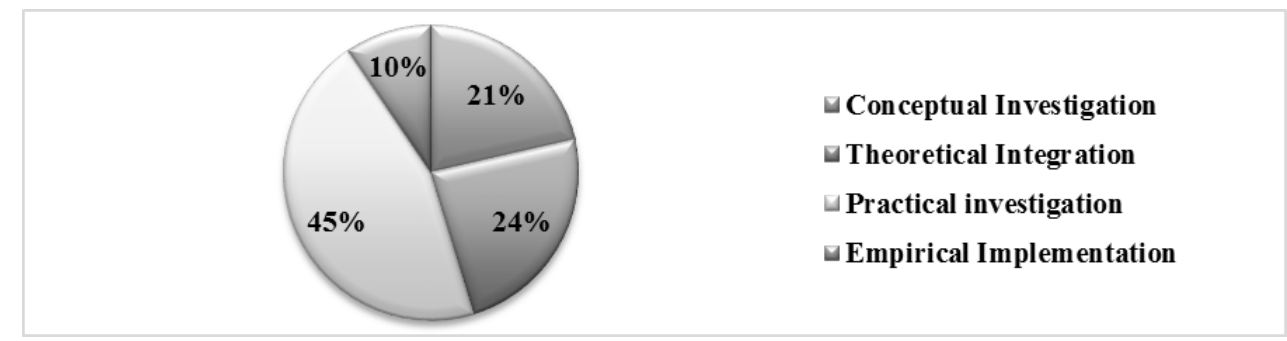

Figure 4: Research purposes and approaches

\section{LIMITATIONS IN APPROACHES TO LC RESEARCH AND PRACTICE}

The study qualitatively synthesised how the reviewed studies highlighted limitations in approaches to LC as well as the suggestions they provided for theoretical integration. A summary of results is shown in Table 2 .

Table 2: Limitations in approaches to LC as identified from the SLR sample

\begin{tabular}{|c|c|}
\hline Author and Year & Categories and Subcategories \\
\hline $\begin{array}{l}\text { Bae and Kim (2007); } \\
\text { Carneiro et al. (2012); } \\
\text { Huovila and Koskela } \\
\text { (1998); Maia et al. (2011); } \\
\text { Maris and Parrish (2016); } \\
\text { Novak (2012); Salvatierra- } \\
\text { Garrido\&Pasquire (2011) }\end{array}$ & $\begin{array}{l}\text { Predominance of a 'limited' customer-focused perspective of 'Value' } \\
\text { - Value delivery is limited to a 'project' rather than a 'global' perspective } \\
\text { - Main focus of lean construction is on client satisfaction and not } \\
\text { necessarily the wider society and environmental performance } \\
\text { - Notion of customer needs to be expanded to include 'all' stakeholders } \\
\text { - The focus of value is on the end product based on clients' needs, which } \\
\text { may not consider environmental impacts } \\
\text { - Value generation must be considered in relation to the external }\end{array}$ \\
\hline
\end{tabular}




\begin{tabular}{|c|c|}
\hline & $\begin{array}{l}\text { environment and social problems } \\
\text { - The notion of value is mostly focussed on waste-reduction rather than } \\
\text { value-creation } \\
\text { - Notion of customer needs to be expanded to include the 'Environment' }\end{array}$ \\
\hline $\begin{array}{l}\text { Arroyo and Gonzalez } \\
\text { (2016); Bae and Kim } \\
\text { (2007); Huovila and } \\
\text { Koskela (1998); Parrish and } \\
\text { Whelton (2013); } \\
\text { Ramkrishnan et al. (2007); } \\
\text { Weinheimer } \text { et al. (2017) }\end{array}$ & $\begin{array}{l}\text { Little focus and attention paid to the management of the project life } \\
\text { cycle requirements (e.g. facilities, operations and maintenance) } \\
\text { - Most studies focus on reducing wastes and costs at the construction } \\
\text { stage only; only a very few take a whole project-life cycle perspective }\end{array}$ \\
\hline $\begin{array}{l}\text { Arroyo and Gonzalez } \\
\text { (2016); Bae and Kim } \\
\text { (2007); Bae and Kim } \\
\text { (2008); Belayutham and } \\
\text { Gonzalez (2015); } \\
\text { Salvatierra-Garrido and } \\
\text { Pasquire (2011)Vieira and } \\
\text { Cachadinha (2011) }\end{array}$ & $\begin{array}{l}\text { The prevailing conceptualisation of 'Waste', which does not account for } \\
\text { environmental and social impacts } \\
\text { - The need for a wider understanding of 'Waste' that should consider } \\
\text { sustainability. } \\
\text { - Traditionally limited in literature to Ohno's } 7 \text { wastes (i.e. TIMWOOD) } \\
\text { - Most studies focus on assessing LC methods from an economic } \\
\text { perspective only }\end{array}$ \\
\hline
\end{tabular}

\section{LIMITATIONS IN APPROACHES TO SUSTAINABLE CONSTRUCTION}

The analysis of this study led to the generation of two overarching limitations in approaches to 'sustainability in architecture and construction', as illustrated in Table 3.

Table 3: Main Limitations in approaches to SC as identified through the SLR

\begin{tabular}{|c|c|}
\hline & \\
\hline $\begin{array}{l}\text { Arroyo and } \\
\text { Gonzalez (2016); } \\
\text { Holloway and } \\
\text { Parrish (2013); } \\
\text { Johnsen and } \\
\text { Drevland (2016); } \\
\text { Novak (2012); } \\
\text { Weinheimer (2016) }\end{array}$ & $\begin{array}{l}\text { The over-reliance on formal 'Green Performance Certifications' (e.g. BREEAM } \\
\text { and LEED), which limits opportunities for sustainability improvement } \\
\text { - Building in a sustainable manner should be pursued whether or not an } \\
\text { environmental performance (e.g. BREEAM or LEED) certification is desired } \\
\text { - LEED certifications as a barrier to sustainability goals outside its frameworks } \\
\text { - Paying less attention to social and economic aspects of sustainability } \\
\text { - Strictly following a criteria catalogue choosing cheapest options or the line of } \\
\text { least effort does not lead to sustainability at large. } \\
\text { - The current small number of Green Buildings does not realistically help in } \\
\text { reducing the greenhouse effect } \\
\text { Focus during certification process is often on achieving credit points, rather than } \\
\text { on adding value to the building and developing a useful concept for it. } \\
\text { BREEAM or LEED lead to extra documentation, causing delays and thus } \\
\text { productivity losses }\end{array}$ \\
\hline $\begin{array}{l}\text { Bae and Kim } \\
(2007) ; \text { Carneiro et } \\
\text { al. (2012); } \\
\text { Holloway and } \\
\text { Parrish (2013); } \\
\text { Koskela and } \\
\text { Tommelein (2009); }\end{array}$ & $\begin{array}{l}\text { Much of the approaches to SC are based on the assumption, in the economic } \\
\text { theory of production, of 'fixed input-output relations' } \\
\text { - Main focus is on design and operational stages of projects, but much less } \\
\text { attention is given to production delivery stage } \\
\text { - Tools and methods used for assessing sustainability impacts of designs/materials } \\
\text { in buildings overlook the means and management of production delivery. }\end{array}$ \\
\hline
\end{tabular}




\begin{tabular}{|c|c|}
\hline $\begin{array}{l}\text { Maris and Parish } \\
(2016) ; \text { Parrish } \\
(2012) ; \text { Rosenbaum } \\
\text { et al. }(2012) ; \\
\text { Weinheimer (2016) }\end{array}$ & $\begin{array}{l}\text { - Sustainable design mainly focusses on health, comfort and welling being of } \\
\text { occupants and the community, but gives less attention to accident reduction and } \\
\text { safety of workers during construction. } \\
\text { - } \text { Focusses on reducing environmental wastes but less attention to process wastes; } \\
\text { - The need for new cost paradigms that consider sustainability 'value', rather than } \\
\text { simply 'costs'. } \\
\text { - Overlooking the significance of contracts and project delivery systems as } \\
\text { 'means to an end' } \\
\text { - Sustainability valuations often overlook or fail to account for differences in } \\
\text { installation and operational time and quality } \\
\text { - Use of 'Prescribed Specifications' in Sustainable Design as opposed to } \\
\text { 'Performance Specifications' in Lean Design } \\
\text { - Reliance on the use of 'Green outcome-based' performance measures, as } \\
\text { opposed to 'process' performance measures in LC } \\
\text { Without an efficient project management and delivery system, a waste of } \\
\text { resources in all possible forms can result, which is not in conformity with the } \\
\text { principles of sustainability }\end{array}$ \\
\hline
\end{tabular}

\section{OPPORTUNITIES FOR FUTURE RESEARCH ON LC AND SUSTAINABILITY}

A comprehensive list of gaps and opportunities for further work has been collated (Table 4). Interestingly, many of these research opportunities are still unfilled and could potentially help to overcome many, if not all, of the flaws and limitations in approaches to LC and SC identified by this study in Tables 2 and 3 above.

Table 4: Opportunities for future research on integrating LC and sustainability

\begin{tabular}{l|l}
\hline Author and Year & \multicolumn{1}{c}{ Categories and Sub categories } \\
\hline $\begin{array}{l}\text { Novak (2012); Saggin } \text { et al. } \\
\text { (2017); Vieira and Cachadinha } \\
(2011) ; \text { Wu and Wang (2016) }\end{array}$ & $\begin{array}{l}\text { Conducting empirical studies to capture the measurable benefits of } \\
\text { integrating LC and sustainability }\end{array}$ \\
\hline Ahuja et al. (2014) & $\begin{array}{l}\text { Developing a BIM-based framework for supporting and measuring LC } \\
\text { and sustainability improvements }\end{array}$ \\
\hline $\begin{array}{l}\text { Arroyo and Gonzalez (2016); } \\
\text { Golzarpoor and Gonzalez } \\
\text { (2013) }\end{array}$ & $\begin{array}{l}\text { Developing a broader list of wastes to eliminate and to account for } \\
\text { environmental and social wastes in all project's lifecycle stages }\end{array}$ \\
\hline $\begin{array}{l}\text { Valente } \text { et al. (2013) } \\
\text { Parrish (2012) }\end{array}$ & $\begin{array}{l}\text { Developing an empirical relationship matrix between LC practices and } \\
\text { green practices related to environmental certifications (e.g. BREEAM) }\end{array}$ \\
\hline $\begin{array}{l}\text { Emuze and Smallwood (2013) } \\
\text { evaluating sustainability options }\end{array}$ & $\begin{array}{l}\text { Development of methodology that would allow the integration of H\&S, } \\
\text { lean and sustainability for the delivery of project value in construction }\end{array}$ \\
\hline $\begin{array}{l}\text { Bae and Kim (2007); Luo et al. } \\
\text { (2005); Golzarpoor and } \\
\text { Gonzalez (2013) }\end{array}$ & $\begin{array}{l}\text { Developing a multi criteria decision-making framework to support the } \\
\text { selection of various lean construction practices for sustainable facilities }\end{array}$ \\
\hline $\begin{array}{l}\text { Holloway and Parrish (2013) } \\
\text { Novak (2012) }\end{array}$ & $\begin{array}{l}\text { Empirical studies quantifying and highlighting life-cycle costs and pay- } \\
\text { back periods to further support growth in sustainable construction }\end{array}$ \\
\hline
\end{tabular}




\begin{tabular}{|c|c|}
\hline & project processes. \\
\hline $\begin{array}{l}\text { Huovila and Koskela (1998); } \\
\text { Novak (2012); Salvatierra- } \\
\text { Garrido and Pasquire (2011) }\end{array}$ & $\begin{array}{l}\text { Examining the opportunity for project 'value' to be understood relative } \\
\text { to a broader perspective of global sustainability value. } \\
\text { - Project value expressed as economic, social \& environmental value } \\
\text { - Widening the concept of value in LC to consider society and future } \\
\text { generations as potential customers }\end{array}$ \\
\hline Weinheimer (2016) & $\begin{array}{l}\text { Identifying and eliminating sources of waste that occur within the } \\
\text { process of obtaining a sustainable building certification }\end{array}$ \\
\hline Bae and Kim (2007) & $\begin{array}{l}\text { Evaluating JIT and pre-fabrication techniques from a holistic } \\
\text { perspective to increase the sustainability of a construction project. }\end{array}$ \\
\hline Valente et al. (2013) & $\begin{array}{l}\text { Incorporating sustainability plans for purchase and installation of } \\
\text { sustainable materials and equipment into LPS look-ahead plans }\end{array}$ \\
\hline $\begin{array}{l}\text { Salvatierra-Garrido and } \\
\text { Pasquire (2011) }\end{array}$ & $\begin{array}{l}\text { Empirical studies to explore how Lean Design can contribute to } \\
\text { enhancing client and social values from an early stage of projects. }\end{array}$ \\
\hline Holloway and Parrish (2013) & $\begin{array}{l}\text { Assessing the changing roles and responsibilities of project stakeholders } \\
\text { in sustainable construction projects }\end{array}$ \\
\hline Gomez et al (2015) & $\begin{array}{l}\text { Investigating the Architectural Technologist's role in linking LC and } \\
\text { sustainability }\end{array}$ \\
\hline $\begin{array}{l}\text { Weinheimer et al. (2017); Bae } \\
\text { and Kim (2007); Arroyo et al. } \\
\text { (2012) and (2013) }\end{array}$ & $\begin{array}{l}\text { Using lean Value Stream Mapping and Choosing by Advantages } \\
\text { techniques for supporting sustainability choices and purposes }\end{array}$ \\
\hline
\end{tabular}

\section{CONCLUSIONS AND RECOMMENDATIONS}

The aim of this study was to systematically review and critically assess the research progress made by the IGLC community, over a span of 25 years, in relation to integrating LC and sustainability principles. SLRs are valuable for their ability to synthesise and uncover connections between separate studies, describe directions for future research, and provide implications for practice and policy. The findings of this study revealed the slow up-take and limited amount of existing research on the topic (only started in 1998 with a total of 41 studies to date). These 41 studies were conducted in, or produced by authors from, 14 different countries, with USA and Brazil leading the research and practice of this topic (more than $50 \%$ of all publications). The study also revealed that only $10 \%$ of the reviewed studies were conducted to empirically implement and quantify the measurable benefits of integrating LC and sustainability.

Three major limitations in approaches to LC were identified: (1) The predominance of a 'limited' customer-focused perspective of 'Value'; (2) The limited focus on the management of project life-cycle requirements; and (3) The prevailing conceptualisation of 'Waste', which does not account for environmental and social impacts. However, two major limitations were associated with approaches to SC: (1) The over-reliance on formal 'Green Performance Certifications', which limits opportunities for sustainability improvement; and (2) Approaches to sustainability in architecture and construction that assume 'fixed input-output relations'. Tackling these identified flaws and exploiting the opportunities for future research collated by this study could certainly help to move the research agenda forward and potentially lead to sustainable improvements in practice. 


\section{REFERENCES}

Elnokaly, A., and Vyas, M. (2014). "A cross case investigation of sustainability assessment tools of the LEED, BREEAM and GRIH." IAPS-23 Conference, Timisoara, Romania.

Huovila, P. and Koskela, L. (1998). "Contribution of the Principles of Lean Construction to Meet the Challenges of Sustainable Development." IGLC-6, Guarujá, Brazil.

Kibert, C. J. (2005). "Resource Conscious Building Design Methods." Sustainable Built Environment, 1, 1-11.

Koladiya, B. (2017). "Research trends of Lean Construction and its compliance with Toyota Production System for year 2016." MSc. in Construction and Real Estate Mgmt., Joint Study Programme of Metropolia UAS and HTW Berlin, $131 \mathrm{pp}$.

Koskela, L., Owen, R., and Dave, B. (2010). "Lean construction, building information modelling and sustainability." ERACOBUILD Workshop, Malmö, Sweden, 1-8.

Koskela, L., (2000). "An exploration towards a theory of production and its application to construction." VTT Publications 408, Technical Research Centre of Finland, Espoo

Koskela, L. (2017). "Why is management research irrelevant?" Construction Management and Economics, 35(1-2: CM: New directions), 4-23.

Lapinski, A., Horman, M., and Riley, D. (2006). "Lean Processes for Sustainable Project Delivery." Journal of Construction Engineering and Management, 132(10), 1083-91.

Leong, M. S. and Tilley, P. (2008). "A Lean strategy to performance measurement Reducing waste by measuring 'next' customer needs'." IGLC-16, Manchester, UK.

Nahmens, I. and Ikuma, L.H. (2012). "Effects of lean construction on sustainability of modular homebuilding." Journal of Architectural Engineering, 18(2), 155-163.

Ogunbiyi, O.J., Goulding, J.S., and Oladapo, A., (2014). "An empirical study of the impact of lean construction techniques on sustainable construction in the UK." Construction Innovation, 14(1), 88-107.

Oyedele, L., Regan, M., Meding, J., Ahmed, A., Ebohon, O., and Elnokaly, A. (2013). "Reducing waste to landfill in the UK: identifying impediments and critical solutions." World J. of Sc., Techn. and Sustainable Development, 10(2), 31-142.

Sarhan, S., Pasquire, C., and King, A. (2017). "The concept of Institutional Waste within the Construction industry: A potential theoretical framework." Lean Construction Journal, 2017 Issue, 12-24.

Sarhan, S., Pasquire, C., King, A., and Manu, E. (2018). "Institutional Waste within the Construction Procurement Context." The Engineering Project Organisation Journal, 8(January 2018), 36-64.

Seymour, D., Crook, D., and Rooke, J. (1997). "The role of theory in construction management: a call for debate." Constr. Management and Economics, 15, 117- 119.

Siddaway, A. (2014). "What is a systematic literature review and how do I do one?" Univ. Stirling, no. Ii, 1-13.

WCED (1987). "Our Common Future: The Brundtland Report." World Commission on Environment and Development, (ed.), Oxford University Press, Oxford, UK.

$\mathrm{Wu}, \mathrm{P}$. and Wang, X. (2016). "A Critical Review of the Factors Affecting the Success of Using Lean to Achieve Green Benefits.” IGLC-24, Boston, USA, Sect.10, pp. 33-42. 